\title{
RESUME PENGERTIAN METODOLOGI ANALISIS
}

\author{
Dwi Febriana \\ Fakultas Komputer \\ Prodi : Sistem Informasi \\ Universitas Mitra Indonesia \\ dwifebriana.student@umitra.ac.id
}

\begin{abstract}
Pada Era Teknologi sekarang,sistem sering digunakan untukmempermudah manusia untuk melakukan segala pekerjaan atau kegiatan baik dari berbelanja,belajarhingga bekerja.

Pengembangan Sistem merupakan salah satu teknik dalam membuat penyususnan suatu sistem yang baru untu kmenggantikan sistem yang lama secara keseluruhan atau memeprbaiki sistem yang telah ada.

Metodelogi Analisis adalah yang digukan untuk memperoleh kebenaran menggunakan penelusuran dengan cara tertentu dalam menemukan kebenaran,metodelogi tersusun daricara cara yang terstrukturuntuk memperolehilmu

KataKunci : Pengertian Metodelogi Analisis
\end{abstract}




\section{A. PENDAHULUAN}

Materi Kuliah audit sistem informasi, section 1 membahas tentang ketertarikan audit, sistem dan metodologi, membahas mengenai pengertian udit, pengertian sistem, pengertian informasi, dan pengertian metedologi analisis dalam pembahsan kali ini saya akan merusume materi audit sistem informasi section 01 tentang pengertian metedologi analisis

B. PEMBAHSAN / STUDI KASUS

Pengertian Metodelogi Analisi, dalam pengertian untuk pengembangan sistem menggunakan metedelogi analisis dan desain terstruktur (structured system analysis and design). Metedologi analisi dan desain terstruktur adalah metedologi ini termasuk kedalam kelompok data oriented methodologies yang menekankan kepada karakteristik dari data yang akan di proses, lebih sepesifik metodelogi snslidid dan desin terstruktur masuk dalam kategori data flowariented methodologies dimana metedelogi ini didasarkan kepada pemecahan dari sistem kedalam modul-modul berdasarkan tipe elemen data dan tingkah laku logika tersebut didalam sistem dengan metodelogi ini sistem dapat digambarkan secara logika ddari arus data yang hubungan antar fungsinya didalam modul-modul di sistem (joygiyanto,2005)

- Tahapan Metedologi Analisis

1. Kebijakan dan perencanaan sistem

2. Analisis Sistem

3. Desain Sistem

4. Seleksi Sistem

5. Implementasi Sistem

\section{ID SECURITY} QWTD4452377-ASP-5244166

\section{KESIMPULAN}

Dari pembahasan diatas dapat disimpulkan pengembangan sistem akan lebih terstruktur dan tergambar apabila kita menggunakan pengembangan dengan metodelogi analisis 


\section{E. DISKUSI}

Saya bersama teman saya bernama Rudi mendiskusikan tentang contoh ini dengan sangat baik Hasil diskusi dari materi ini adalah.

Pengembangan metodrlogi analisis sangat penting untuk memperoleh kebenaran menggunakan penelusuran dengan cara tertentu dalam menemukan kebenaran dan pemecahan dari sistem kedalam modul-modul berdasarkan tingkah laku elemen data dan tingkah laku logika tersebut dapat digambarkan secara logika dari arus data dan hubungan antar fungsinya.

\section{F. REFERENCE}

[1] O. M. Febriani and A. S. Putra, "Sistem Informasi Monitoring Inventori Barang Pada Balai Riset Standardisasi Industri Bandar Lampung," J. Inform., vol. 13, no. 1, pp. 90-98, 2014.

[2] A. S. Putra, "Paperplain: Execution Fundamental Create Application With Borland Delphi 7.0 University Of Mitra Indonesia," 2018.

[3] A. S. Putra, "2018 Artikel Struktur
Data, Audit Dan Jaringan Komputer," 2018.

[4] A. S. Putra, "ALIAS MANAGER USED IN DATABASE DESKTOP STUDI CASE DB DEMOS."

[5] A. S. Putra, "COMPREHENSIVE SET OF PROFESSIONAL FOR DISTRIBUTE COMPUTING."

[6] A. S. Putra, "DATA ORIENTED RECOGNITION IN BORLAND DELPHI 7.0."

[7] A. S. Putra, "EMBARCADERO DELPHI XE 2 IN GPU-POWERED FIREMONKEY APPLICATION."

[8] A. S. Putra, "HAK ATAS KEKAYAAN INTELEKTUAL DALAM DUNIA TEKNOLOGY BERBASIS REVOLUSI INDUSTRI 4.0."

[9] A. S. Putra, "IMPLEMENTASI PERATURAN PERUNDANGAN UU. NO 31 TAHUN 2000 TENTANG DESAIN INDUSTRI BERBASIS INFORMATION TECHNOLOGY."

[10] A. S. Putra, "IMPLEMENTATION OF PARADOX DBASE."

[11] A. S. Putra, "IMPLEMENTATION OF TRADE SECRET CASE STUDY SAMSUNG MOBILE PHONE."

[12] A. S. Putra, "IMPLEMENTATION PATENT FOR APPLICATION WEB BASED CASE STUDI WWW. PUBLIKLAMPUNG. COM."

[13] A. S. Putra, "IMPLEMENTATION SYSTEM FIRST TO INVENT IN DIGITALLY INDUSTRY." 
A. S. Putra, "MANUAL REPORT \& INTEGRATED DEVELOPMENT ENVIRONMENT BORLAND DELPHI 7.0."

[15] A. S. Putra, "PATENT AS RELEVAN SUPPORT RESEARCH."

[16] A. S. Putra, "PATENT FOR RESEARCH STUDY CASE OF APPLE. Inc."

[17] A. S. Putra, "PATENT PROTECTION FOR APPLICATION INVENT."

[18] A. S. Putra, "QUICK REPORT IN PROPERTY PROGRAMMING."

[19] A. S. Putra, "REVIEW CIRCUIT LAYOUT COMPONENT REQUIREMENT ON ASUS NOTEBOOK."

[20] A. S. Putra, "REVIEW TRADEMARK PATENT FOR INDUSTRIAL TECHNOLOGY BASED 4.0."

[21] A. S. Putra, "TOOLBAR COMPONENT PALLETTE IN OBJECT ORIENTED PROGRAMMING."

[22] A. S. Putra, "WORKING DIRECTORY SET FOR PARADOX 7."

[23] A. S. Putra, "ZQUERY CONNECTION IMPLEMENTED PROGRAMMING STUDI CASE PT. BANK BCA Tbk."

[24] A. S. Putra, D. R. Aryanti, and I. Hartati, "Metode SAW (Simple Additive Weighting) sebagai Sistem Pendukung Keputusan Guru Berprestasi (Studi Kasus: SMK Global Surya)," in Prosiding Seminar Nasional Darmajaya, 2018, vol. 1, no. 1, pp. 85-97.

[25] A. S. Putra and O. M. Febriani,
"Knowledge Management Online Application in PDAM Lampung Province," in Prosiding International conference on Information Technology and Business (ICITB), 2018, pp. 181-187.

[26] A. S. Putra, O. M. Febriani, and B. Bachry, "Implementasi Genetic Fuzzy System Untuk Mengidentifikasi Hasil Curian Kendaraan Bermotor Di Polda Lampung," SIMADA (Jurnal Sist. Inf. dan Manaj. Basis Data), vol. 1, no. 1, pp. 21-30, 2018.

[27] A. S. Putra, H. Sukri, and K. Zuhri, "Sistem Monitoring Realtime Jaringan Irigasi Desa (JIDES) Dengan Konsep Jaringan Sensor Nirkabel," IJEIS (Indonesian J. Electron. Instrum. Syst., vol. 8, no. 2, pp. 221232.

[28] D. P. Sari, O. M. Febriani, and A. S. Putra, "Perancangan Sistem Informasi SDM Berprestasi pada SD Global Surya," in Prosiding Seminar Nasional Darmajaya, 2018, vol. 1, no. 1, pp. 289-294. 